\section{Amiata donkey milk chain: animal health evaluation and milk quality} Martina Benedetti, ${ }^{1}$ Ilaria Paladini, ${ }^{1}$ Federica Salari, ${ }^{2}$ Iolanda Altomonte, ${ }^{3}$ Mina Martini ${ }^{3,4}$

${ }^{1}$ Institute for Experimental Veterinary Medicine of Lazio and Tuscany, Scandicci (FI); ' Interdepartmental Centre of AgroEnvironmental Research Enrico Avanzi, University of Pisa, Pisa; ${ }^{3}$ Department of Veterinary Sciences, University of Pisa, Pisa; ${ }^{4}$ Interdepartmental Research Center Nutraceuticals and Food for Health, Pisa, Italy

\section{Abstract}

This study presents an investigation of Amiata donkey health and quality of milk for human consumption. Thirty-one lactating dairy jennies were examined. The following samples were collected: faecal samples from the rectum of animals for parasitological examination; cervical swabs for the detection of bacteria causing reproductive disorders; and blood samples for serological diagnosis of main zoonotic (Brucella spp., Leptospira spp.) and donkey abortion agents (Brucella spp., Leptospira spp., Salmonella abortus equi, Equine viral arterithis virus, Equine herpesvirus type 1). In addition, individual milk samples were collected and analysed for mastitis-causing pathogens and milk quality. Regarding animal health, we detected a high prevalence of strongyle parasites in donkeys. It is very important to tackle parasitic diseases correctly. Selective control programmes are preferable in order to reduce anthelmintic drug use. For dairy donkeys, withdrawal periods from anthelmintic drugs need to be carefully managed, in accordance with EU and national regulations. The isolation of Staphylococcus aureus in milk highlights the importance of preventing contamination during milking, by adopting appropriate hygiene and safety practices at a farm level. Lysozyme activity was high compared to cow's milk, contributing to the inhibitory activity against certain bacteria. Donkey milk was characterised by high lactose content, low caseins, low fat, higher levels of unsaturated fatty acids compared to ruminant milks. Unsaturated fatty acids and omega 3 fatty acids in particular have become known for their beneficial health effect, which is favourable for human diet. These characteristics make it suitable for infants and children affected by food intoler- ance/allergies to bovine milk proteins and multiple food allergies as well as for adults with dyslipidemias. It is also recommended to prevent cardiovascular diseases.

\section{Introduction}

Donkeys are docile and rural equids, traditionally used as working animals and now also used in onotherapy (donkey assisted therapy) for children and hiking.

Interest in donkey milk has recently increased, especially in Europe, as it represents an alternative food in cases of bovine milk proteins allergy and in the prevention of metabolic pathologies (Trinchese et al., 2015). Donkey milk has a somewhat similar chemical composition to human milk (Vincenzetti et al., 2008). Recently, the growing importance of milk production from species other than cattle, including donkeys, has been also highlighted in tackling the growing global demand for milk (Faye and Konuspayeva, 2012).

The Amiata donkey is a local breed native to

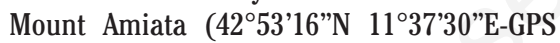
cooordinates) between the provinces of Siena and Grosseto, in the heart of Tuscany (Central Italy).

The Amiata population is a descendant of the North African donkey. It has its roots at a time when the Etruscan civilisation was flourishing and occupied most of Central Italy (www.filieraippicatoscana.it). In 1800, Amiata donkeys were recognised as a homogeneous population. As a result of industrialisation, however, Amiata donkeys decreased dramatically in number and became endangered in the 1980s. In 1993, the breed was officially recognised (Martini and Salari, 2012). Still, programmes to protect and promote these donkeys have only recently been put in place enabling the population to reach the current number of about 2300 heads, more than double compared to 2005 (http://www. anagrafeequidi.it/).

An Amiata donkey milk supply chain was recently created in Tuscany, which represents a focus point for the protection of this breed. The creation of an innovative system focusing on donkey milk is particularly interesting for Central European and Mediterranean countries, where native donkey breeds are strongly decreasing in numbers.

In addition, the lack of specific legislation for the production and marketing of donkey milk for human nutrition means that biological, chemical and physical evaluations have to be carried out in order to guarantee the nutritional quality and food safety.

In the light of the increasing interest in donkey milk, this study presents an investigation of some aspects of animals' health and quality
Correspondence: Mina Martini, Department of Veterinary Sciences, University of Pisa, viale delle Piagge 2, Pisa 56124, Italy.

Tel: +39.050 .2216897 .

E-mail:mina.martini@unipi.it

Contributions: the authors contributed equally to this work

Conflict of interest: the authors declare no potential conflict of interest.

Funding: the study was supported by the contribution of the regional government of Tuscany: Direzione Generale dei Diritti di Cittadinanza e Coesione Sociale - Settore Ricerca, Innovazione e Risorse umane - Bando pubblico per progetti di ricerca nel settore Nutraceutica.

Acknowledgements: the authors would like to thank the Complesso Agricolo Forestale Regionale Bandite di Scarlino, Scarlino, Italy.

Key words: Donkey health; Pathogen; Milk hygiene; Milk quality.

Received for publication: 22 April 2016.

Revision received: 24 June 2016.

Accepted for publication: 24 June 2016.

This work is licensed under a Creative Commons Attribution-NonCommercial 4.0 International License (CC BY-NC 4.0).

(C) Copyright G. Ragona et al., 2016

Licensee PAGEPress, Italy

Italian Journal of Food Safety 2016; 5:5951

doi:10.4081/ijfs.2016.5951

characteristics of Amiata donkey milk for human consumption.

\section{Materials and Methods}

\section{Animals and samplings}

The sampling was carried out in a farm in Tuscany (Italy), within the native area of the Amiata donkey breed. The donkeys were reared outdoors and were fed grass hay ad libitum and about $2.5 \mathrm{~kg} / \mathrm{d}$ per head of commercial pelleted concentrate for dairy jennies. The jennies were routinely machine-milked and the foals were physically separated from their dams three hours before milking.

Thirty-one lactating dairy jennies were examined. Pulse and respiration rates and body temperature were recorded, and body condition scores (BCS) were evaluated during the first examination (Svendsen, 2008). Due to the lack of information on the presence of infectious diseases in dairy donkeys, a sanitary screening protocol was designed encompassing udder health and the main reproduc- 
tive, gastro-intestinal and respiratory disorders.

The following samples were collected from each jenny: one faecal sample for parasitological analysis; one cervical swab for detection of bacteria causing reproductive disorders, and one blood sample for serological diagnosis of the main zoonotic (Brucella spp., Leptospira spp.) and donkey abortion agents (Brucella spp., Leptospira spp., Salmonella abortus equi, Equine viral arterithis virus, Equine herpesvirus type 1). In addition, during the different stages of lactation, four milk samples were collected from each animal (31 jennies). Two samples from each animal were taken in the period between the $2^{\text {nd }}$ and $5^{\text {th }}$ lactation month $(31 \times 2=62$ samples), and 2 samples were taken between the $6^{\text {th }}$ and $9^{\text {th }}$ lactation month $(31 \times 2=62$ samples). A total of 124 individual samples were analysed for the detection of mastitis causative bacteria and for milk quality.

\section{Animal health evaluation}

Faecal samples were collected from the rectum, stored in sterile containers at $4^{\circ} \mathrm{C}$ until delivery to the laboratory, and analysed within $24 \mathrm{~h}$ as follows (Thienpont et al., 1986): flotation test with a low density solution [sodium chloride ( $\mathrm{NaCl})$ saturated solution-s.g. 1.200] to detect intestinal helminths; McMaster assay with a sensitivity of 50 eggs per $\mathrm{g}$ (epg) to evaluate intestinal parasites count; Baermann technique to detect Dyctiocaulus arnfieldi larvae; faecal sedimentation to detect trematode eggs. Cervical swabs were processed in order to detect Taylorella equigenitalis, Klebsiella pneumoniae, Pseudomonas aeruginosa and Streptococcus equi zooepidemicus (OIE, 2008). The jennies who were positive for one of these bacteria were further tested after two weeks.

Blood serum was collected from the jugular vein using Vacutainer ${ }^{\circledR}$ tubes and stored at $+4^{\circ} \mathrm{C}$ until delivery to the laboratory. The samples were obtained by centrifugation and stored at $-20^{\circ} \mathrm{C}$ until testing. Sera were tested as shown in Table 1. For the detection of mastitis causative bacteria, $10 \mathrm{~mL}$ of milk were aseptically collected from each half udder in sterile containers, stored at $+4^{\circ} \mathrm{C}$ until delivery to the laboratory, and analysed within $3 \mathrm{~h}$. Each milk sample was plated on Blood agar, MacConkey agar, Baird Parker agar and
Edwards Medium agar and processed according to the Laboratory handbook on bovine mastitis (National Mastitis Council, 1999). Agar plates were incubated at $37^{\circ} \mathrm{C}$ and examined for growth at 24 and $48 \mathrm{~h}$. Identification was performed by morphological analysis, Gram staining, and biochemical tests (API ${ }^{\circledR}$ system). Pathogens were also tested for antimicrobial susceptibility by the agar disk diffusion method (Bauer et al., 1966). The tested antimicrobials were amoxicillin-clavulanate, cefoperazone, neomycin, penicillin, streptomycin and tetracycline.

\section{Milk quality analysis}

Individual milk samples were analysed in duplicate for dry matter, fat and lactose by infrared analysis (Milkoscan; Italian Foss Electric, Padua, Italy); total proteins, caseins and ash content were also determined (AOAC, 2005).

The lysozyme activity was tested in all the milk samples by a fluorimetric method within six hours of milking (EnzCheck Lysozyme Assay kit; Invitrogen, Carlsbad, CA, USA). The method is based on the lysis of Micrococcus lysodeycticus marked with fluorescein. The lysozyme activity was measured by a fluorometer (Salita; Thermo Labsystem, Helsinki, Finland) using excitation of $494 \mathrm{~nm}$ and emission of $518 \mathrm{~nm}$, and expressed as $\mathrm{U} / \mathrm{mL}$.

The diameter and the number of fat globules

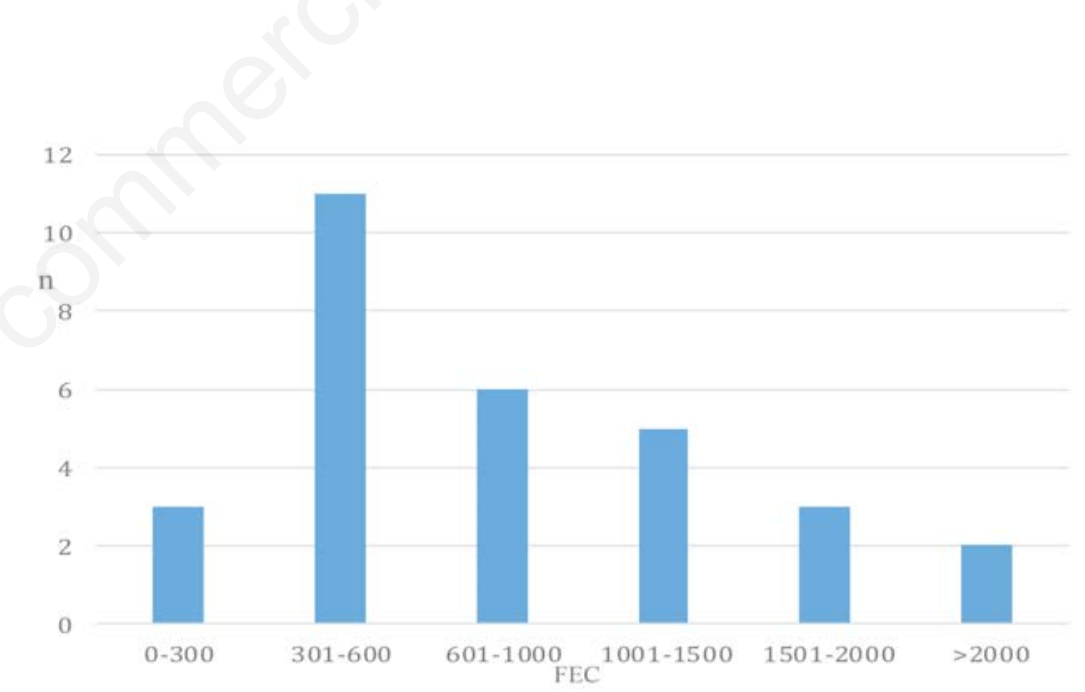

Figure 1. Stratification of animals (n) in relation to faecal egg count. per mL of milk in each sample were measured by florescence microscopy following a direct method (Martini et al., 2013). Milk fat extraction was performed following Rose-Gottlieb's method (AOAC, 2000). Fatty acid profile was assessd as follows: methyl esters (FAME) were prepared using methanolic sodium methoxide according to Christie (1982). A Perkin Elmer Auto System (Perkin Elmer, Waltham, MA, USA) GC equipped with a flame ionisation detector and a capillary column (30 $\mathrm{m} \times 0.25$ $\mathrm{mm}$; film thickness $0.25 \mathrm{~mm}$; FactorFour Varian, Middelburg, Netherlands) was used. The helium carrier gas flow rate was 1 $\mathrm{mL} \cdot \mathrm{min}^{-1}$. The oven temperature programme was as follows: level $1,50^{\circ} \mathrm{C}$ held for $2 \mathrm{~min}$; level 2,50 to $180^{\circ} \mathrm{C}$ at $2^{\circ} \mathrm{C} \cdot \mathrm{min}^{-1}$ then held for $20 \mathrm{~min}$; level 3,180 to $200^{\circ} \mathrm{C}$ at $1^{\circ} \mathrm{C} \cdot \mathrm{min}^{-1}$ then held for $15 \mathrm{~min}$; and finally level 4, 200 to $220^{\circ} \mathrm{C}$ at $1^{\circ} \mathrm{C} \cdot \mathrm{min}^{-1}$ then held for $30 \mathrm{~min}$. The injector and detector temperatures were set at 270 and $300^{\circ} \mathrm{C}$, respectively. The peak areas of individual fatty acids (FA) were identified using an FA standard injection (Sigma-Aldrich Chemical Co., St. Louis, MO, USA). Saturated (SFA), monounsaturated (MUFA), polyunsaturated (PUFA) classes were calculated as follows: $\mathrm{SFA}=\sum \mathrm{C} 4: 0, \mathrm{C} 6: 0, \mathrm{C} 8: 0, \mathrm{C} 10: 0, \mathrm{C} 11: 0$, C12:0, C13:0, C14:0, C15:0, C16:0, C17:0, C18:0, $\mathrm{C} 20: 0, \mathrm{C} 21: 0, \mathrm{C} 22: 0, \mathrm{C} 23: 0, \mathrm{C} 24: 0$; MUFA $=\sum$ C14:1, C15:1, C16:1, C17:1, C18:1 t9, C18:1 t11, C18:1c9, C20:1, C22:1, C24:1; PUFA= $\sum$ C18:2

Table 1. Infectious agents investigated by serological analysis.

\begin{tabular}{lcc}
\hline Infectious agents & Tests & References \\
Brucella spp. & Rose Bengale test & (OIE, 2008; chapter 2.4.3 part 2.a) \\
\hline Equine Viral Arteritis virus & Virus neutralisation test & (OIE, 2008; chapter 2.5.10 part 2.a) \\
Equine Herpes Virus type I & Virus neutralisation test & (OIE, 2008; chapter 2.5.9 part 2.1) \\
\hline L. interrogans (Bratislava, Pomona, & Microscopic agglutination test & (OIE, 2008; chapter 2.1.9 part 2.1) \\
Icterohaemorrhagiae and Saxkoebing) & & (OIE, 2008; chapter 2.9.9) \\
Salmonella abortus equi & Direct agglutination test (micromethod) &
\end{tabular}


t9,12, C18:2 c9,12, C18:3 n6, C18:3 n3, C20:2, C20:3 n6, C20:4, C20:3 n3, C20:5, C22:2, C22:5, C22:6.

\section{Results and Discussion}

\section{Animal health evaluation}

Clinical parameters are shown in Table 2. All the jennies showed a good health status since the clinical parameters were consistent with the physiological range for donkeys (Svendsen, 2008).

Parasitological, bacteriological and virological assays results are shown in Table 3.

Strongyle eggs were found in 30 donkeys (96.77\%), while Oxiuris equi eggs were found in one faecal sample (3.22\%). Mean strongyle faecal egg count (FEC) was $886.67 \mathrm{epg}$, with a minimun value of $50 \mathrm{epg}$ and a maximum value of $2850 \mathrm{epg}$, and a standard deviation of 669.01 epg. Oxiuris equi $\mathrm{FEC}$ was $50 \mathrm{epg}$.

Dyctiocaulus arnfieldi was found in six donkeys (19.35\%), while Fasciola hepatica was never detected.

There are only a few data available on the prevalence of donkey parasites. Moreover such studies have been carried out in extra-EU countries, where donkeys are reared for work purposes and live in a different environment and management conditions. The strongyle prevalence in different countries is: 95.297.1\% in South Africa (Wells et al., 1998), 99.5\% in Ethiopia (Asefa et al., 2011), and 80\% in Mexico (Burden et al., 2010). In Italy different studies have been also carried out, showing different prevalences: $77 \%$ (Giannetto et al., 2008) and 93\% (Veneziano, 2011).

The high prevalence of strongyles in the farm that we investigated may be related to the management conditions (free outdoor pad- docks) and to the lack of parasite control programmes. In fact, a study on the efficacy of different parasite control strategies (selective and strategic therapies) is still in progress. It is important to plan a parasite control programme in food-producing animals in order to guarantee animal welfare and animal health, taking into account a reduction in anthelmintic drug use.

The pharmacological control of donkey parasites can be difficult due to the lack of licensed anthelmintic products and the increasing prevalence of anthelmintic resistance (Matthews and Burden, 2013; Lawson et al., 2015). This problem may be related to the application of therapeutic protocols designed for horses, using the same drug doses. Differences in pharmacokinetic and pharmacodynamic drug properties between horses and donkeys have been observed, as therapeutic doses used in horses has not been effective in donkeys (Grosenbaugh et al., 2011).

A total of 27 of the tested animals showed a strongyle FEC above the cut-off value of 300 epg (Figure 1) (Matthews and Burden, 2013). Donkeys with a high FEC did not show any clinical sign of disease, as also described by Burden et al. (2010).
A selective or targeted therapy of strongyle infection, by treating only the animals with a FEC above the cut-off value, is preferable to a strategic therapy (Matthews and Burden, 2013).

The aims of a targeted therapy are to decrease selection pressure for anthelmintic resistance, to maintain animal health, and to ensure food safety.

Dyctiocaulus arnfieldi had the second highest prevalence in our study. None of the positive cases showed respiratory signs of disease, which confirms that this parasite does not cause any disease in healthy donkeys. Nonetheless, it is important to reduce $D$. arnfieldi infection, especially in old and immunocompromised animals or in mixed equine herds. Eprinomectin (EPM) administered as a pour-on preparation and at a dose rate reccomended for cattle is effective against $D$. arnfieldi infection in donkeys (Veneziano et al., 2011). The low level of excretion of EPM in donkey milk, which is lower than the maximum residue limit in bovine milk $(20 \mu \mathrm{g} / \mathrm{kg})$ (WHO/FAO, 1999), led to take into account the use of EPM in lactating donkeys at cattle dosage of $0.5 \mathrm{mg} / \mathrm{kg}$ body weight, thus avoiding any risk to food safety (Gokbulut et al., 2012).

Table 2. Mean, standard deviation, minimum and maximum values of clinical parameters.

\begin{tabular}{lccc} 
& Mean \pm SD & Min & Max \\
BCS & $3.6 \pm 0.506$ & 3 & 4 \\
Temperature $\left({ }^{\circ} \mathrm{C}\right)$ & $37.06 \pm 0.265$ & 36.6 & 37.5 \\
\hline Pulse (beats/min) & $40.52 \pm 4.589$ & 32 & 48 \\
Respiration (breaths/min) & $21.16 \pm 3.891$ & 16 & 32 \\
\hline
\end{tabular}

BCS, body condition scores; SD, standard deviation.

Table 3. Parasitological, bacteriological and virological assays and prevalence.

\begin{tabular}{|c|c|c|c|c|}
\hline Classes of disease & & Sample & Agents & Prevalence (\%) \\
\hline Parasites & $\begin{array}{l}\text { Intestinal } \\
\text { Respiratory } \\
\text { Hepatic }\end{array}$ & Faeces & $\begin{array}{c}\text { Strongyles } \\
\text { Oxiuris equi } \\
\text { Dyctiocaulus arnfieldi } \\
\text { Fasciola hepatica }\end{array}$ & $\begin{array}{c}96.77 \\
3.22 \\
19.35 \\
0\end{array}$ \\
\hline Reproductive bacterial disorders & & Cervical swab & $\begin{array}{c}\text { Taylorella equigenitalis } \\
\text { Klebsiella pneumoniae } \\
\text { Streptococcus equi zooepidemicus } \\
\text { Pseudomonas aeruginosa }\end{array}$ & $\begin{array}{c}0 \\
6.44 \\
9.68 \\
0\end{array}$ \\
\hline Infectious diseases & & Blood serum & $\begin{array}{c}\text { Brucella spp. } \\
\text { Leptospira spp. } \\
\text { Salmonella abortus equi } \\
\text { Equine arteritis virus } \\
\text { Equine herpesvirus type } 1\end{array}$ & $\begin{array}{l}0 \\
0 \\
0 \\
0 \\
0\end{array}$ \\
\hline Udder health & $\begin{array}{l}\text { First sample } \\
\text { Second sample }\end{array}$ & Individual milk & $\begin{array}{c}\text { Mastitic agents } \\
\text { Staphylococcus aureus } \\
\text { Streptococcus equi zooepidemicus }\end{array}$ & $\begin{array}{c}0 \\
3.22 \\
6.44\end{array}$ \\
\hline
\end{tabular}


Microbiological analysis of cervical swabs showed the presence of Streptococcus equi subspecies zooepidemicus and Klebsiella pneumoniae, in three and two animals, respectively, with no clinical signs of reproductive diseases. Streptococcus equi subspecies zooepidemicus and Klebsiella pneumoniae, with Pseudomonas aeruginosa, represent commensal bacterial flora of genital system of equids (Samper Tibary, 2006), so the isolation of these potential pathogenic bacteria alone is not sufficient evidence for diagnosis of endometritis. In stress conditions they can grow and proliferate, leading to clinical disorders. The positive females were tested again after two weeks and none of them were found to be positive for the previous isolated bacteria.

Serological tests showed no antibodies against the infectious agents tested. Brucellosis in equids is rare. In Europe there are no studies on the prevalence of this disease in donkeys, while in Nigeria a prevalence of $5 \%$ has been reported (Sadiq et al., 2013).

All the individual milk samples collected during the first lactation period were negative for mastitic agents, while during the second lactation period Staphylococcus aureus and Streptococcus equi subsp. zooepidemicus were isolated in one and in two samples, respectively. These isolates were further tested by the agar diffusion method and none of them showed resistance to any of the antibiotics tested.

These results confirm the low prevalence of mastitic agents in donkeys (Pilla et al., 2010) due to the peculiar anatomy of the equid udder, which is well supported and sufficiently raised with respect to the ground. An additional reason is the antimicrobial activity of donkey milk due to the natural antimicrobial substances. A mastitic bacteria control programme is recom- mended however, because zoonotic bacteria isolation in apparently healthy animals can be a risk for end-consumers. This risk can be high if donkey milk is consumed raw, without any heat treatment. Methicillin resistant Staphylococcus spp. has been isolated in donkey milk in Italy (Naccari et al., 2009).

\section{Milk quality analysis}

Table 4 shows the average composition of Amiata donkey milk. The dry matter content is consistent with other donkey breeds, and lower than human and bovine milk (Martini et al., 2014).

These differences between donkey $v s$ human and cow milk are due to the milk nutritional components of the different species. Amiata donkey milk has a closer protein profile and lactose content to human than bovine milk. The lower total proteins compared to cow's milk, and above all the lower content of total caseins, make donkey milk suitable for children allergic to cow milk proteins as also reported by Polidori and Vincenzetti (2013). The low casein content favours milk digestibility (Tidona et al., 2011); in addition, similarly to mare and human milks it may cause the formation of a flocculent precipitate in the stomach, which decreases the bowel transit time (Malacarne et al., 2002).

The low proteins contribute to a similar low renal solute load to breastfed children (Salimei and Fantuz, 2012). In fact, protein intake during infancy needs to be monitored due to the lifelong effect on kidney volume and function, and to obesity risk (Michaelsen and Greer, 2014).

The lactose content, which is similar to human milk, is much higher compared to bovine milk (Martini et al., 2014). Lactose improves the palatability of donkey milk

Table 4. Amiata donkey milk composition $(n=124)$.

\begin{tabular}{lc}
\hline Gross composition $(\mathrm{g} / 100 \mathrm{~mL})$ & $1.57 \pm 0.248$ \\
Protein & $0.75 \pm 0.030$ \\
Casein & $0.40 \pm 0.196$ \\
Fat & $7.23 \pm 0.243$ \\
Lactose & $0.37 \pm 0.061$ \\
Ash & $9.38 \pm 0.546$ \\
Dry matter & \\
Milk FA classes and globule diameter & $56.65 \pm 8.304$ \\
Saturated FAs (g/100g of total FAs) & $22.17 \pm 8.184$ \\
Monounsaturated FAs (g/100g of total FAs) & $21.18 \pm 4.051$ \\
Polyunsaturated FAs (g/100g of total FAs) & $0.80 \pm 0.347$ \\
Unsaturated:saturated FA ratio & $1.65 \pm 0.185$ \\
n6:n3 ratio & $2.12 \pm 0.712$ \\
Diameter of the milk fat globules $(\mu \mathrm{m})$ & \\
\hline Lysozyme & $3986.21 \pm 277.80$ \\
Activity (U/mL of milk) & \\
Somatic cell count & $9.06 \cdot 103 \pm 3.67 \cdot 103$ \\
Number of cells per $\mathrm{mL}$ & \\
\hline FA, fatty acid. Values are expressed as means \pm standard deviation.
\end{tabular}

(Polidori and Vincenzetti, 2012) and stimulates the absorption of calcium in the intestine (Klobukowski et al., 2014), contributing to calcium homeostasis. Calcium is considered as a nutraceutical for geriatrics (Gupta and Prakash, 2015) and its bioavaiability in donkey milk supports its use in geriatric nutrition.

The total minerals in Amiata donkey milk are intermediate between human and bovine (Martini et al., 2014).

Similarly to the findings of Vincenzetti et al. (2008) in milk from other donkey breeds, Amiata milk also has an inhibitory activity against certain bacteria, probably due to the lysozyme content. The lysozyme content in donkey milk is very similar to that found in human milk, whereas only traces have been detected in bovine milk (Vincenzetti et al., 2008; Uniacke-Lowe et al., 2010). These differences are linked to the fact that the antimicrobial activity of human, horse and donkey milk is mainly determined by lysozyme and lactoferrin, whereas lactoperoxidase and immunoglobulins are the main defense systems in bovine milk (Uniacke-Lowe et al., 2010; Hettinga et al., 2011).

In our study the average lysozyme actvity was high compared to cow's milk and similar to the lower value observed by Pilla et al. (2010) in the same donkey breed, whereas higher values have been reported in herds of crossbreeds, Martina Franca, and Ragusana donkeys (Cavallarin et al., 2015). The differences with the study by Cavallarin et al. (2015) could be linked to endogenous and physiological factors (breed and lactation period) as well as the sample processing. In fact, although not significant, a progressive increased lysozyme activity has been found in raw milk during sample storage at $4^{\circ} \mathrm{C}$ (Addo and Ferragut, 2015). Amiata donkey milk could be considered as a diet food due to the low-fat content, compared to the average fat percentages of bovine and human breast milk. These characteristics along with the low energy value and hypolipidemic effects (Trinchese et al., 2015) make donkey milk potentially exploitable for people suffering from obesity or cardio-vascular problems. n6:n3 ratio (1.65) in our study was lower compared to conventional and organic cow milk (5.77 and 2.28, respectively) (Benbrook et al., 2013): this is a positive feature according the position of the Academy of Nutrition and Dietetics, which recommends in adults diets an increased consumption of $\mathrm{n} 3$ fatty acids (Vannice and Rasmussen, 2014). However, the low fat may not make donkey milk nutritionally adequate for unweaned babies. This obstacle is still surmountable with appropriate lipid additions (Sarti et al., 2016).

The analysis of the morphometric characteristics of donkey milk fat globules highlighted an average diameter of $2.12 \mu \mathrm{m}$, which is lower than human (3-5 $\mu \mathrm{m})$ and cow milk (3.5-5.5 $\mu \mathrm{m})$ 
(Gallier et al., 2015; Martini et al., 2016).

The small size of the fat globules favours the digestibility of the milk. Furthermore, the smallest globules have a higher surface/volume ratio compared to the larger globules, and this contributes to a greater membrane intake in milk, which in turn contributes to the intake of various bioactive elements and polyunsaturated fatty acids (Martini et al., 2013). In fact, in the milk analysed, the unsaturated:saturated fatty acid ratio was more similar to human (1.1) (Mäkelä et al., 2013) than bovine (2.06) milk (Soyeurt et al., 2008)

\section{Conclusions}

Regarding animal health, we confirmed the high prevalence of strongyle parasites in donkeys. It is very important to tackle parasitic diseases correctly, by proper diagnosis and pharmacological therapy with a suitable drug dosage. Selective control programmes are preferable in order to reduce anthelmintic drug use. For dairy donkeys, withdrawal periods from anthelmintic drugs need to be carefully managed, in accordance with regulations 470/2009/EC and 37/2010/EC (European Commission, 2009, 2010). The isolation of Staphylococcus aureus in milk highlights the importance of preventing contamination in the primary production, by adopting appropriate hygiene practices that ensure the achievement of the objectives of Regulation 852/2004/EC (European Commission, 2004). Donkey milk is characterised by high lactose content, low fat, and higher levels of unsaturated fatty acids compared to ruminant milk. Unsaturated fatty acids and omega 3 fatty acids in particular have become known for their beneficial health effect. A good unsaturated:saturated ratio and n6:n3 ratio can be considered favourable for human diet. Milk quality characteristics support its use in infants and children affected by food intolerance/allergy to bovine milk proteins and multiple food allergies, in adults, in the elderly with dyslipidaemias, and in the prevention of cardiovascular diseases.

\section{References}

Addo CNA, Ferragut V, 2015. Evaluating the ultra-high pressure homogenization (UHPH) and pasteurization effects on the quality and shelf life of donkey milk. Int $\mathrm{J}$ Food Stud 4:104-15.

AOAC, 2000. Official methods of analysis. 17th ed. AOAC International, Gaithersburg, MD, USA.

AOAC, 2005. Official methods of analysis. 18th ed. AOAC International, Gaithersburg, MD, USA.
Asefa Z, Kumsa B, Endebu B, Gizachew A, Merga T, Debela E, 2011. Endoparasites of donkeys in Sululta and Gefersa districts of Central Oromia, Ethiopia. J Anim Vet Adv 10:1850-4.

Bauer AW, Kirky WM, Sherris JC, Turck M, 1966. Antibiotic susceptibility testing by a standardized single disk method. Am J Clin Pathol 45:493-6.

Benbrook CM, Butler G, Latif MA, Leifert C, Davis DR, 2013. Organic production enhances milk nutritional quality by shifting fatty acid composition: a United States-wide, 18-month study. PLoS ONE 8:82429.

Burden FA, Du Toit N, Hernandez-Gil M, PradoOrtiz 0, Trawford AF, 2010. Selected health and management issues facing working donkeys presented for veterinary treatment in rural Mexico: some possible risk factors and potential intervention strategies. Trop Anim Health Pro 42:597-605.

Cavallarin L, Giribaldi M, Soto-Del Rio MD, Valle E, Barbarino G, Gennero MS, Civera T, 2015. A survey on the milk chemical and microbiological quality in dairy donkey farms located in Northwestern Italy. Food Control 50:230-5.

Christie WW, 1982. A simple procedure for rapid transmethylation of glycerolipids and cholesteryl esters. J Lipid Res 23:10725.

European Commission, 2004. Regulation of the European Parliament and of the Council of 29 April 2004 on the hygiene of foodstuffs, 852/2004/CE. In: Official Journal, L 139/1, 30/04/2004.

European Commission, 2009. Regulation of the European Parliament and of the Council of 6 May 2009 laying down Community procedures for the establishment of residue limits of pharmacologically active substances in foodstuffs of animal origin, repealing Council Regulation (EEC) No 2377/90 and amending Directive 2001/82/EC of the European Parliament and of the Council and Regulation (EC) No 726/2004 of the European Parliament and of the Council, 470/2009/CE. In: Official Journal, L 152/11, 16/06/2009.

European Commission, 2010. Regulation of the European Parliament and of the Council of 22 December 2009 on pharmacologically active substances and their classification regarding maximum residue limits in foodstuffs of animal origin, 37/2010/CE. In: Official Journal, L 15/1, 20/01/2010.

Faye B, Konuspayeva G, 2012. The sustainability challenge to the dairy sector. The growing importance of non-cattle milk production worldwide. Int Dairy J 24:50-6.

Gallier S, Vocking K, Post JA, Van De Heijning B, Acton D, Van Der Beek EM, Van Baalen T,
2015. A novel infant milk formula concept: mimicking the human milk fat globule structure. Colloids Surface B 136:329-39.

Giannetto S, Poglayen G, Brianti E, 2008. [I parassiti dell'asina, dall'immagine all'azione]. In: Conte F, ed. [L'asino all'attenzione della comunità scientifica e del territorio]. [Book in Italian]. Chiriotti Editore, Pinerolo, Italia, pp 32-6.

Gokbulut C, Naturali S, Rufrano D, Anastasio A, Yalinkilinc HS, Veneziano V, 2012. Plasma disposition and milk excretion of eprinomectin following pour-on administration in lactating donkeys. J Vet Pharmacol Ther 36:302-5.

Grosenbaugh DA, Reinemeyer CR, Figueiredo MD, 2011. Pharmacology and therapeutics in donkeys. Equine Vet J 23:523-30.

Gupta C, Prakash D, 2015. Nutraceuticals for geriatrics. J Tradit Complement Altern Med 5:5-14.

Hettinga $\mathrm{K}$, van Valenberg $\mathrm{H}$, de Vries $\mathrm{S}$, Boeren S, van Hooijdonk T, van Arendonk J, Vervoort J, 2011. The host defense proteome of human and bovine milk. PLoS ONE 6:e19433.

Klobukowski JA, Skibniewska KA, Kowalski IM, 2014. Calcium bioavailability from dairy products and its release from food by in vitro digestion. J Elementol 19:277-88.

Lawson E, Burden F, Elsheikha HM, 2015. Pyrantel resistance in two herds of donkey in the UK. Vet Parasitol 207:346-9.

Mäkelä J, Linderborg K, Niinikoski H, Yang B, Lagström H, 2013. Breast milk fatty acid composition differs between overweight and normal weight women: the STEPS study. Eur J Clin Nutr 52:727-35.

Malacarne M, Martuzzi F, Summer A, Mariani $\mathrm{P}, 2002$. Protein and fat composition of mare's milk: some nutritional remarks with reference to human and cow's milk. Int Dairy J 12:869-77.

Martini M, Salari F, Altomonte I, 2016. The macrostructure of milk lipids: the fat globules. Crit Rev Food Sci 56:1209-21.

Martini M, Salari F, 2012. [Valorizzare il latte di asina, un progetto per la filiera]. [Article in Italian]. Informatore Agrario 46:1-5.

Martini M, Altomonte I, Salari F, 2013. Evaluation of the fatty acid profile from the core and membrane of fat globules in ewe's milk during lactation. Food Sci Technol Leb 50:253-8.

Martini M, Altomonte I, Salari F, 2014. Amiata donkeys: fat globule characteristics, milk gross composition and fatty acids. Ital $\mathrm{J}$ Anim Sci 13:123-6.

Matthews JB, Burden FA, 2013. Common helminth infections of donkeys and their control in temperate regions. Equine Vet Educ 25:461-7.

Michaelsen KF, Greer FR, 2014. Protein needs 
early in life and long-term health. Am J Clin Nutr 99:718-22.

Naccari F, Foti M, Giacopello C, Mariavitale P, Passantino A, Russo C, Conte F, 2009. Methicillin resistant Staphylococcus sp isolated from donkey's milk in Sicily: preliminary study. In: Proceedings of 1th International Congress of the European Association for Veterinary Pharmacology and Toxicology, 12-16 July 2009, Leipzig, Germany, p 150.

National Mastitis Council, 1999. Laboratory handbook on bovine mastitis. National Mastitis Council, Verona, WI, USA.

OIE, 2008. Manual of diagnostic tests and vaccines for terrestrial animals. World Organisation for Animal Health, Paris, France.

Pilla R, Daprà V, Zecconi A, Piccinini R, 2010. Hygienic and health characteristics of donkey milk during a follow-up study. J Dairy Res 77:392-7.

Polidori P, Vincenzetti S, 2012. Protein profile characterization of donkey milk. In: Hurley WL, ed. Milk protein. Intech, Rijeka, Croatia, pp 215-32.

Polidori P, Vincenzetti S, 2013. Use of donkey milk in children with cow's milk protein allergy. Foods 2:151-9.

Sadiq MA, Tijani A-N, Auwal MS, Mustapha AR, 2013. Serological prevalence of brucellosis among donkeys (Equus asinus) in some local government areas of Yobe State, Nigeria. J Equine Vet Sci 33:150-4.

Salimei E, Fantuz F, 2012. Equid milk for human consumption. Int Dairy J 24:13042.
Samper JC, Tibary A, 2006. Disease transmission in horses. Theriogenology 66:551-9.

Sarti L, Martini M, Ragona G, Casati D, Belli F, Salari F, Altomonte I, Barni S, Mori F, Pucci $\mathrm{N}$, Novembre E. [Il latte d'asina di razza Amiatina nella gestione del bambino con allergia alle proteine del latte vaccino]. In: Proceedings of the 10th International Forum of Practical Nutrition NutriMI, 2122 April 2016, Milan, Italy. [Proceedings in Italian].

Soyeurt H, Dardenne P, Dehareng F, Bastin C, Gengler N, 2008. Genetic parameters of saturated and monounsaturated fatty acid content and the ratio of saturated to unsaturated fatty acids in bovine milk. J Dairy Sci 91:3611-26.

Svendsen ED, 2008. The professional handbook of the donkey. 4th ed. Whittest Books, London, UK.

Thienpont D, Rochette F, Vanparijs OFJ, 1986. L'esame coprologico nella diagnosi delle elmintiasi. 2nd ed. Janssen Research Foundation, Beerse, Belgium.

Tidona F, Sekse C, Criscione A, Jacobsen M, Bordonaro S, Marletta D, Vegarud GE, 2011. Antimicrobial effect of donkeys' milk digested in vitro with human gastrointestinal enzymes. Int Dairy J 21:158-65.

Trinchese G, Cavaliere G, Berni Canani R, Matamoros S, Bergamo P, De Filippo C, Aceto S, Gaita M, Cerino P, Negri R, Greco L, Cani PD, Mollica MP, 2015. Human, donkey and cow milk differently affects energy efficiency and inflammatory state by modulating mitochondrial function and gut microbiota. J Nutr Biochem 26:1136-46.
Uniacke-Lowe T, Huppertz T, Fox PF, 2010. Equine milk proteins: chemistry, structure and nutritional significance. Int Dairy $\mathbf{J}$ 20:609-29.

Vannice G, Rasmussen H, 2014. Position of the Academy of Nutrition and Dietetics: dietary fatty acids for healthy adults. J Acad Nutr Diet 114:136-53.

Veneziano V, 2011. [I principali endoparassiti dell'asino: biologia e controllo]. In: Milonis E and Polidori P, eds. [Latte di asina produzione, caratteristiche e gestione dell'azienda asinine]. [Book in Italian]. Fondazione Iniziative Zooprofilattiche e Zootecniche, Brescia, Italy, pp 75-90.

Veneziano V, Di Loria A, Masucci R, Di Palo R, Brianti E, Gokbulut C, 2011. Efficacy of eprinomectin pour-on against Dyctiocaulus arnfieldi infection in donkeys (Equus asinus). Vet J 190:414-5.

Vincenzetti S, Polidori P, Mariani P, Cammertoni N, Fantuz F, Vita A, 2008. Donkey's milk protein fractions characterization. Food Chem 106:640-9.

Wells D, Krecek RC, Wells M, Guthrie AJ, Lourens JC, 1998. Helminth levels of working donkeys kept under different management systems in the Moretele 1 district of the North-West Province, South Africa. Vet Parasitol 77:163-77.

WHO/FAO, 1999. Joint FAO/WHO Expert Committee on food additives. Residues of some veterinary drugs in animals and foods. WHO/FAO, Rome, Italy. 